\title{
An appraisal of eco-friendly silica-sand mining activity located at Great Boundary Fault in Bundi District of Rajasthan, India-A case study.
}

\author{
S. K. Maanju*Deepak Rawal* \\ *Vikram University, Ujjain(M.P.)India
}

\begin{abstract}
The friable quartzite zone near Barodia in Bundi district of Rajasthan has been met with almost continuously for a distance of about 1,400 yards in a general $E$ - $W$ direction. It is developed along the slopes of a chain of quartzite ridges, near the base of the lower Bhander quartzites. The width of this zone as measured on a horizontal plane varies from 50 to 300 feet. The depth of the friable zone is not known and could not be determined. The friable rock, however, has been met upto a depth of 25 feet in the existing workings and can be reasonably assumed to extend up to a depth of at least 50 feet. The good plantation indicates eco-friendly mining activity in the mine site of silica sand mining.
\end{abstract}

Key words: Silica-sand, Great Boundary Fault, Eco-friendly Mining etc.

\section{Introduction}

The Barodia Silica Mine falls on toposheet map no. 45 0/11, located at (N $25^{\circ}-28^{\prime}-2^{\prime \prime}$ E $75^{\circ}-35^{\prime}$ $00 "$ ) and $10 \mathrm{Km}$ North -West from Bundi town in Rajasthan State and also lies on the N. H. No. 12( Jaipur to Jabalpur). The mine lies on the east of village Satoor located at N. H. 12 and. The Barodia Silica Sand M. L. area is situated in the hilly range. The name of the owner is Shri K. L. Ghatiwala,Rishabh Bhawan,New Colony Gumanpura, Kota.

\section{Geology}

In Bundi district of RajasthanState, the glass-sand deposits near Barodia occurs in the Lower Bhander group of the Vindhyan supergroup. This formation is very extensively developed in the Bundi district both to the north and south of Bundi town, where the rocks are folded into a series of anticlines and synclines. Generally the dip is $30^{\circ}$, but it is sometimes as high as $80^{\circ}$. Petrologically, the formation consists of sandstones, quartzites and grit. The lower beds are usually fine-grained, red and compact, followed by a great thickness of white quartzite with grit at the base. The glass-sand deposit near Barodia is actually a zone of soft grit in the main quartzite formation.

\section{Role Of Great Boundary Fault}

This area of mine is famous in Geology due to great boundary fault. The deposits of Silica sand have been formed along this great boundary fault striking NW-SE and dipping due SW. The great boundary fault has brought in juxtaposition two rock groups by uplifting the pre- Aravalli rocks by about 500 meters. Due to this , the Vindhyan sandstones have become friable in the form of workable Silica sand deposits. The great boundary fault in general extends over $400 \mathrm{~km}$. from West of Chittorgarh in Rajasthan to NW of Fatehpur Sikari in U.P.State of India.

\section{Properties Of Glass Making Sands}

The essential properties for sand to be suitable for glass manufacture are :-

(i) a low $\mathrm{Fe}_{2} \mathrm{O}_{3}$ content

(ii) friable nature and

(iii) a medium and approximately uniform size of grains.

The percentage of $\mathrm{Fe}_{2} \mathrm{O}_{3}$ which may be allowed in a glass-sand depends upon the quality of the glass to be produced. In the case of optical and best crystal glass, the $\mathrm{Fe}_{2} \mathrm{O}_{3}$ content should be 0.02 percent and the maximum allowed being 0.05 percent whereas for plate glass, $\mathrm{Fe}_{2} \mathrm{O}_{3}$ upto 0.2 percent is permissible and $\mathrm{Fe}_{2} \mathrm{O}_{3}$ upto 0.5 percent can be used for the manufacture of window glass and white bottles etc. Alumina was formerly considered an objectionable impurity but is now some-times intentionally added in the form of feldspar, lepidolite, etc. , however, its content must be uniform. The $\mathrm{CaO}$ and $\mathrm{MgO}$ are not objectionable if present in small quantities.

The rock should be friable otherwise it is difficult and costly to crush. Uniformity of grain size is very desirable. Glass sands should not be coarser than 20 to 30 meshes and should not be finer than 100 to 120 
meshes as coarser sand requires very high temperature and too much time for fusion while very fine sand may be carried away by the draught in the furnace. Sand dust melts readily but balls up and causes imperfections in the glass.

The glass-making sand near Barodia in the Bundi district is nothing but a soft grit zone in the lower Bhander quartzite. The formation of this grit may be attributed to the slight variation in the composition of the quartzite zone which has been softened and appears to be comparatively more felspathic and has therefore been kaolinised, thus loosening the quartz grains in the rock. The kaolinisation plausibally brought about by meteoric waters. There is presence of a zone of ferruginous material varying in thickness from a few inches to five feet or occasionally even more on the top usually followed by a thin zone of broken rock stained with iron oxide and then friable quartzite (grit) or the glass sand rock. The iron oxide on the top appears to have been derived from the quartzite and brought up by capillary action.

The color of the glass sand rock varies considerably at different places at the same depth and depends on the percentage of ferruginous matter in the rock. Apart from other factors, the color of the glass sand is appreciably influenced by the color of the original quartzite. Generally speaking pure white sand is considered to be the best and the brownish sand the most inferior in quality. There are various shades of the brownish color in between the two extremes. The color of the sand gives a fair indication of the percentage of iron and is practically the only means of determining the quality in the field.

The sand requires washing before it can be used in optical glass. Washing will be done by water after eliminating particles below 100 meshes and after washing the sand will be sieved through 100 meshes again.

Sieve Tests: The results of sieve test of Barodia mines are tabulated below.

\begin{tabular}{|c|c|c|c|c|c|c|}
\hline Sample No. & On 20 Mesh & On 40 Mesh & On 60 Mesh & On 80 Mesh & On 100 Mesh & Passing $100 \mathrm{Mesh}$ \\
\hline & $(\%)$ & $(\%)$ & $(\%)$ & $(\%)$ & $(\%)$ & $(\%)$ \\
\hline $\mathrm{SNP} / 1 \mathrm{G}$ & 16.65 & 58.40 & 17.10 & 3.15 & 0.53 & 4.17 \\
\hline $\mathrm{SNP} / 2 \mathrm{G}$ & 2.77 & 25.35 & 56.42 & 7.76 & 1.85 & 6.12 \\
\hline $\mathrm{SNP} / 3 \mathrm{G}$ & 4.38 & 19.55 & 53.69 & 11.48 & 2.30 & 8.60 \\
\hline $\mathrm{SNP} / 4 \mathrm{G}$ & 20.92 & 52.90 & 20.18 & 2.9 & 0.83 & 3.27 \\
\hline $\mathrm{SNP} / 5 \mathrm{G}$ & 4.60 & 13.20 & 31.30 & 23.50 & 4.50 & 22.90 \\
\hline $\mathrm{SNP} / 6 \mathrm{G}$ & 2.93 & 10.65 & 8.40 & 8.88 & 12.49 & 56.65 \\
\hline $\mathrm{SNP} / 7 \mathrm{G}$ & 23.80 & 28.90 & 19.50 & 7.10 & 0.70 & 20.10 \\
\hline
\end{tabular}

\begin{tabular}{|l|c|c|}
\hline Sample No. & $\mathbf{S i O}_{2}$ Percent & $\mathbf{F e}_{2} \mathbf{O}_{3}$ Percent \\
\hline $\mathrm{SNP} / 1 \mathrm{G}$ & 99.34 & 0.015 \\
\hline $\mathrm{SNP} / 2 \mathrm{G}$ & 98.48 & 0.052 \\
\hline $\mathrm{SNP} / 3 \mathrm{G}$ & 97.26 & 0.055 \\
\hline $\mathrm{SNP} / 4 \mathrm{G}$ & 98.56 & 0.110 \\
\hline $\mathrm{SNP} / 5 \mathrm{G}$ & 89.40 & 0.140 \\
\hline $\mathrm{SNP} / 6 \mathrm{G}$ & 89.74 & 0.104 \\
\hline $\mathrm{SNP} / 7 \mathrm{G}$ & 90.74 & 0.100 \\
\hline
\end{tabular}

Source (Data supplied by Management of Mine)

The samples of the eastern part of the deposit near Barodia viz., SNP/5G, SNP/6G and SNP/7G have a large proportion of finer material and have also low silica content. As this finer material is mainly clayey matter, these samples cap be greatly improved with regard to their grain size and silica content by removing the material finer than 100 meshes either with the help of a sieve or by washing. The grain size in the other samples from the area is fairly uniform and is on the whole suitable for the manufacture of glass. The samples SNP/1G, SNP/2G and $\mathrm{SNP} / 3 \mathrm{G}$ have $\mathrm{Fe}_{2} \mathrm{O}_{3}$ content less than 0.05 percent and are therefore regarded as suitable for the manufacture of optical and best crystal glass. The $\mathrm{Fe}_{2} \mathrm{O}_{3}$ content in the other samples is above 0.1 percent, which is rather too high for optical and best crystal glass, but is well within the permissible limit of 0.2 percent for plate glass. All the samples are suitable for the manufacture of window glass, white bottles etc. so far as the $\mathrm{Fe}_{2} \mathrm{O}_{3}$ content is concerned.

\section{Chemical Composition Of Silica-Sand}

The essential properties for sand to be suitable for glass manufacturing require low $\mathrm{Fe}_{2} \mathrm{O}_{3}$ contents and a friable nature of sand. The Barodia silica sand is good friable in nature with very low contents of $\mathrm{Fe}_{2} \mathrm{O}_{3}$ and most suitable for manufacture of glass. Silica chemical test report from M/s. Italab Private Limited, Bombay is as under :-

\begin{tabular}{|l|c|c|}
\hline Silica & $\mathrm{SiO}_{2}$ & 98.65 Percent \\
\hline Alumina & $\mathrm{Al}_{2} \mathrm{O}_{3}$ & 00.38 Percent \\
\hline Ferric Oxide & $\mathrm{Fe}_{2} \mathrm{O}_{3}$ & 00.04 Percent \\
\hline Titanium Dioxide & $\mathrm{TiO}_{2}$ & Nil \\
\hline Manganous Oxide & $\mathrm{MnO}$ & Nil \\
\hline Calcium Oxide & $\mathrm{CaO}$ & Nil \\
\hline
\end{tabular}


An appraisal of eco-friendly silica-sand mining activity located at Great Boundary Fault in ....

Source (Data supplied by Management of Mine Owner)

Mineable Reserves :Deposit wise mineable reserves are as follows:-

\begin{tabular}{|l|r|}
\hline Deposit & Mineable Reserves (Tons) \\
\hline Deposit at Pit No. 1 & 436484 Western Block \\
\hline Deposit at Pit No. 2 & 12920360 Western Block \\
\hline Deposit at Pit No. 3 & 4648445 \\
\hline Total & 4.65 Million Tons \\
\hline Round-off & Block \\
\hline
\end{tabular}

Source (Data supplied by Management of Mine Owner)

\section{Anticipated Life of Mine}

As the total mineable reserve of Silica sand is estimated about 4.65 million tonnes. As per the mining plan the production for the first two years was 30,000 and 37,500 tonnes and after that the production is expected to be increased up to 45,000 tonnes yearly. Thus the deposit will last for more than 100 years.

List Of Afforestation/Plantation Within M. L. Area

\begin{tabular}{|l|l|c|}
\hline FRUIT TREE & Mango & 26 \\
& Coconut & 02 \\
& Chiku & 04 \\
& Jamun & 03 \\
& Barbee & 13 \\
& Gauva Tree & 26 \\
& Karonda & 60 \\
& Leswa & 07 \\
\hline OTHER TREE & & 141 \\
& U Cliptus & 3180 \\
& Sambhu & 255 \\
& Neem & 92 \\
& Shisham & 392 \\
& Khegra & 10 \\
& Khar & 05 \\
& Chhola & 05 \\
& Babool & 46 \\
& Ashoka & 29 \\
& Bard (Baniyan) & 02 \\
& Pipal & 03 \\
& Siras & 06 \\
& Gular & 01 \\
& Kaneer & 30 \\
& Mogra & 350 \\
& Gulab & 55 \\
\hline & & 4,461 \\
\hline
\end{tabular}

Source (Data supplied by Management of Mine)

\section{Conclusion}

The total area covered by the zone of friable quartzite on a horizontal plane is 5,81,200 square feet. Assuming 50 feet as the averages of the friable zone, the reserves of friable quartzite (glass sand) are 29,060,000 cubic feet. Taking 20 cubic feet of friable quartzite to be equivalent to 1 ton, the total reserves including already worked out come to $1,162,400$ tons or round-off as $1,162,000$ tons. Taking note of plantation, the mining activity of this area may be considered as an eco-friendly.

\section{Acknowledgement}

The second author is very thankfully acknowledge the all tabular data received from Management of Barodia silica- sand mine during field visit of the site.

\section{References}

[1]. Bear, J. and Bachmat, Y. (1966). Hydrodynamic dispersion in non-uniform flow through porous media taking in to account density and viscosity differences. Hydrol. Lab. Tech., Haifa, Israel, I.A.S.H., pp. 4166.

[2]. Blanford, W.T., 1876. On the physical geology of the Great Rajasthan Desert, J. Asiatic Soc. Bengal, $45: 86-103$.

[3]. 3 Crawford, A.R. and Compston, W., 1970. The age of Vindhyan System of Peninsular India. Quart. J. Geol. Soc.India, 125: 351-371. 
[4]. Crookshank, H., 1948. Tectonic elements of west Rajasthan shelf and their stratigraphy Quat. Jour. Geol. Min. Met. Soc. Ind. 50: 116.

[5]. Gupta, S.N. Arora, Y.K., Mathur, R.K., lqbaluddin, Balmiki Prasad Sahai, T.N., sharma, S.B., 1980. Lithostratigraphic map of Aravalli region southern Rajasthan and NE Gujrat. Geol. Surv. India, Western Region, Jaipur.

[6]. Gupta, B.C., 1934. The Geology of Central Mewar, Rajputana, Mem. Geol Surv. India. 65:110-1169.

[7]. Hacket, C.A., 1877. Note on the aravalli Series in northeastern Rajputana. Rec. Geol. Surv. India, 10(2) : 84.

[8]. Hacket, C.A. 1881. On the Geology of the Aravalli Region, Central and Eastern Rajputana. Rec. Geol. Surv. India, 14(4) : 279-303.

[9]. Heron, A.M., 1932. The Vindhyans of western Rajputana. Rec. Geol. Surv. India, 65(4) : 457-489.

[10]. Heron, A.M., 1935. Synopsis of the Pre-Vindhyan Geology of Rajputana, Trans. Nat. Inst. India, 1:1-17.

[11]. Heron, A.M., 1953. The Geology of Central Rajputana. Mem. Geol Surv. India, 79(1) : 389.

[12]. Johnson, A.I., Morris, D.A. and Prill, R.C. (1966). Specific yield of porous media, an annotated bibliography : U.S. Geol. Survey open file report. Kelly, W.E. (1977). Geoelectrical sounding for estimating aquifer hydraulic onductivity.

[13]. La Touche, T.H.D., 1902. Geology of Western Rajputana. Mem. Geol. Surv. India, 35(1) : 1-116.

[14]. Mohanty, S. and Naha, K., 1986. Stratigraphic relations of the Precambrian rocks in the Salumbar area, southeastern Rajasthan. J. Geol. Soc. India. 27(6) : 479-493.

[15]. Naha, K. and Halyburton, R.V., 1974. Early Precambrain Stratigraphy of Central and southern Rajasthan, India. Precambrain Research.

[16]. Naha, K. and Roy, A.B., 1983. the problem of Precambrian basement in Rajasthan, western India. Precambrain Research, 19: $217-$ 223.

[17]. Oldham, R.D. (1893). Manual of Geology of India, GSI, Calcutta.

[18]. Roy, A.B., Paliwal, B.S., Shekhwat, S.S., Nagori, D.K., Golani, P.R. and Bejarniay, B.R. (1988.) Stratigraphy of the Aravalli Supergroup in the type area. Mem. Geol. Soc. India 7: 121-138. 